\title{
THE USE OF CHARITY AS A MEANS OF POLITICAL LEGITIMATION \\ IN UMAYYAD AL-ANDALUS*
}

Ana María CARBALLEIRA DEBASA

debasa@eea.csic.es

Escuela de Estudios Árabes (CSIC), Granada

\begin{abstract}
The principal aim of this study is to examine the use of charity as a factor of political legitimation by the ruling elite of al-Andalus in the Umayyad period. Accordingly, it explores the degree to which charity was an instrument in the hands of the authorities, and the manner in which this strategy was decisive in the process of consolidating power. In a broader sense, this analysis enables us to deepen our knowledge of the political elite in al-Andalus and to elucidate how charitable attitudes reflected a particular conception of power.
\end{abstract}

\section{Keywords}

Legitimation, politics, charity, social history, al-Andalus, Umayyad period

\section{Introduction}

The issue of political legitimacy in Islam has generated a wealth of bibliography. One of the aspects that have received the most attention is the way in which caliphal legitimacy was articulated in the pre-modern Islamic world. Regarding al-Andalus, our knowledge about the Umayyad caliphs of Cordoba has grown due to a series of works that, in addition to examining their ideology as developed in the historiography, also analyse representations of legitimacy in a wide variety of forms and contexts. ${ }^{1}$ But research into Umayyad caliphal ideology goes further; this is demonstrated by some studies that have dealt with the continuity of the meaning of this ideology

* Research for this paper has been carried out within the project "Documents from Nasrid and Mudejar Granada: a study of the collections (law, economy and society)" (FFI2012-37775), funded by the Spanish Ministry of Economy and Competitiveness. I am grateful to Anne Marie Wolf for her assistance in preparing the English translation of this article.

1 Works associated with this theme will be mentioned throughout the present article. 
after the collapse of the Umayyad regime in al-Andalus, reaching the conclusion that the taifa kings attempted to assert their own legitimacy through association of their authority with the caliphate of Cordoba. ${ }^{2}$

Although a considerable number of studies have explored concepts of political legitimacy among the al-Andalus Umayyads', scarcely any attention has been paid to charity exercised by rulers as a tool of political legitimation. ${ }^{3}$ By contrast, the utilization of charity for political ends in other Islamic contexts has been given substantial attention by the scholarly community. Indeed, for al-Andalus in the Nasrid period one study demonstrated that the foundation and later funding of a charitable institution, the hospital (māristān) of Granada, was part of a programme of political-religious legitimation. ${ }^{4}$ But the political use of charity in Andalusi society was neither exclusive nor excluding, since it was also generalized in the rest of the Muslim world, as the extensive bibliographic corpus on the question confirms. Besides some recent contributions

2 F. Clément, Pouvoir et légitimité en Espagne musulmane à l'époque des taifas (Ve-XIe siècles): L'ímām fictif(Paris: L'Harmattan, 1997); P. Guichard and B. Soravia, Les royaumes des taifas. Apogée culturel et déclin politique des émirats andalous du XIème siècle (Paris: Geuthner, 2007); P.C. Scales, The Fall of the Caliphate of Córdoba: Berbers and Andalusis in Conflict (Leiden: Brill, 1994); D.J. Wasserstein, Caliphate in the West: an Islamic Political Institution in the Iberian Peninsula (New York: Clarendon Press, 1993). For a bibliographical review of these last two works, see M. Fierro, "On political legitimacy in al-Andalus: A review article.” Der Islam 73 (1996): 138-50.

${ }^{3}$ A superficial approach to this subject may be found within the framework of some general studies on poverty and charity in al-Andalus: A.M. Carballeira Debasa, "Pobres y caridad en al-Andalus.” In Identidades marginales (Estudios Onomástico-Biográficos de al-Andalus XIII), ed. C. de la Puente (Madrid: CSIC, 2003): 74-5; eadem, "Forms and Functions of Charity in al-Andalus." In Charity and Giving in Monotheistic Religions, ed. Y. Lev and M. Frenkel (Berlin: De Gruyter, 2009): 208-9; eadem, “Caridad y poder político en época omeya." In Caridad y compasión en biografías islámicas (Estudios Onomástico-Biográficos de al-Andalus XVI), ed. A.M. Carballeira Debasa (Madrid: CSIC, 2011): 97-106. See also M. Fierro, “Apuntes sobre la pobreza y su representación en las sociedades del Occidente islámico medieval (ss. II/VIII-IX/XV)”. In XXXVI Semana de Estudios Medievales de Estella, 20 a 24 de julio de 2009 (Pamplona: Gobierno de Navarra, Institución Príncipe de Viana, 2010): 145-174. Hence the expediency of devoting an exhaustive analysis to an aspect that at present has not been dealt with in a case study itself.

${ }^{4}$ A. Peláez Rovira, “El Maristán de Granada al servicio del poder nazarí: el uso político de la caridad.” In Caridad y compasión en biografías islámicas: 131-70. 
related to the Maghreb, ${ }^{5}$ most of the scholarship demonstrating the importance of charity as a strategy to reinforce the legitimacy of political power concerns the Islamic East. ${ }^{6}$

With regard to aspects of legitimation and the symbolic manifestation of the Umayyad government of al-Andalus, this study examines charity dispensed by sovereigns in order to determine the meaning and functions of these pious works, with special reference to their political implications. One of the purposes of this contribution is to reconsider the dynamic relations that arose between the political elite and the rest of society, exploring the degree to which charity was an instrument in the hands of the authorities and how this strategy functioned in the rulers' efforts to consolidate power. This analysis can also reveal how charitable attitudes reflected a particular conception of power. Toward this end, we offer new data to understand how Andalusi Umayyad sovereigns defined their authority. All these elements will enable us to deepen our knowledge of the political elite in al-Andalus. ${ }^{7}$ In a wider framework, this study seeks to contribute to the study of political legitimacy in pre-modern Islamic societies.

To undertake this task, the chronicles prove most eloquent, although one must not ignore the information contained in biographical dictionaries, since they supply interesting data. Arabic historical sources that deal with the Umayyads of al-Andalus devote particular attention to the personality of each monarch, offering a reconstruction of their moral qualities, in addition to their physical appearance or the exercise of their political and military power. Unfortunately, the brevity of the textual references not always allows us to go beyond the available information. Moreover, one can wonder whether the beneficent acts reported in the biographical portrayals of the Umayyad rulers of al-Andalus should be understood as a form of panegyric to extol the figure of the authorities by the chroniclers, who wrote their works while under the patronage of the rulers. As we will see below, in some cases it is clear that the sources' discourse uses the charitable image in a eulogizing and legitimizing tone, suggesting minimal correspondence between the portrayals of rulers' virtues and the reality of their characters. However, a detailed examination of the texts shows the degree to which authors incorporate variables that cannot always be

${ }^{5}$ One case that has received substantial attention is that of the Marinid sultans, who combined political action and religious propaganda through an exemplary ethical profile; see M. El Mansour, "Hospitality, Charity and Political Legitimacy." In The Articulation of Power in Medieval Iberia and the Maghrib, ed. A.K. Bennison (Oxford: Oxford University Press, 2014): 175-91; M.J. Viguera Molins, "La compasión, virtud del sultán, en el Musnad de Ibn Marzūq." In Caridad y compasión en biografías islámicas: 173-206.

${ }^{6}$ By way of example, see the works by M. Ener, S. Heidemann, Y. Lev, N. Özbek, O. Peri and A. Singer in the final bibliography.

${ }^{7}$ A general study of the Andalusi political elite in the Umayyad period can be found in M. Meouak, Pouvoir souverain, administration centrale et élites politiques dans l'Espagne umayyade (IIe-IVe/VIIIe-Xe siècles) (Helsinki: Academia Scientiarum Fennica, 1999). 
reduced to the category of historiographical cliché. Whatever the case, while Arabic sources may indeed reflect conventionalised praise, they nevertheless do contain interesting notions of good government, thus offering clues to how political image was created and functioned in al-Andalus in the Umayyad period. All these documents provide the foundation for the arguments and perspectives presented here.

\section{1. "Classical" instruments of political legitimation in Umayyad al-Andalus}

If by political legitimacy we understand a concept argued by a power to justify its government and attract broad sectors of the population in order to guarantee their submission, legitimation includes the set of actions and attributes that lead to the acceptance of a ruler as the legitimate holder of power. The legitimation of government in pre-modern Islamic societies is a complex issue. The Umayyads of al-Andalus employed a series of typical mechanisms of legitimation in Islam, established through custom and practice. ${ }^{8}$ These mechanisms were adapted to local geopolitical exigencies, which included the assimilation of the Hispano-Roman-Visigoth legacy. ${ }^{9}$

The first emirs of al-Andalus sought correspondence with legitimate dynastic powers; although they claimed the Visigoth past as their own, ${ }^{10}$ the central argument in their programme of legitimation was the recovery of the legacy of their Syrian ancestors. After the Umayyad restoration of the caliphate by 'Abd al-Raḥmān III al-Nāṣir in 316/929, Andalusi caliphs not only championed the legitimacy of the dynastic legacy of the Syrian Umayyad caliphate, but also staked

8 These are formulas also used by other regimes in the pre-modern Islamic world; see, for instance, M. Fierro, "La legitimidad del poder en el Islam." Awrāq 15 (1994): 155-6; A. Nef, "Instruments de la légitimation politique et légitimité religieuse dans l'Ifrīqiya de la fin du IX siècle: l'exemple d'Ibrāhīm II (875-902)." In La légitimation du pouvoir au Maghreb médiéval. De l'orientalisation à l'émancipation politique, ed. A. Nef and É. Voguet (Madrid: Casa de Velázquez, 2011): 75-91.

9 This assimilation reached a point where sarcophagi and Roman sculptures were reused in the caliphal court of Cordoba. It might be taken as a deliberate action to exalt the Hispanic heritage in legitimization of the Cordoban caliphate. See S. Calvo Capilla, "Madīnat al-Zahrā' y la observación del tiempo: el renacer de la Antigüedad Clásica en la Córdoba del siglo X." Anales de Historia del Arte 22 (2012): 131-60; eadem, "The Reuse of Classical Antiquity in the Palace of Madinat al-Zahra' and its Role in the Construction of Caliphal Legitimacy." Muqarnas Online 31 (2014): 1-33.

10 The weight of a prior monarchical tradition worked in favour of the establishment of an emirate in the Iberian Peninsula by 'Abd al-Raḥmān I, the last survivor of the Abbasid purge of the Umayyads in Syria in 132 AH/750 AD. See Bennison (ed.), The Articulation of Power in Medieval Iberia: 15-16. 
their claim as defenders of Sunni Islam on the traditional authority of the four rightly guided caliphs who succeeded the Prophet Muhammad.11

'Abd al-Raḥmān III distinguished his caliphate from those of his Abbasid and Fatimid rivals by his support for the Maliki madhhab. Recent publications show that the expansion of Sunni orthodoxy by Maliki ulemas in the Islamic West contributed to the legitimation of sovereigns and their dynasties. Ulemas, as repositories of religious knowledge and the interpretation of divine law, had the power to legitimize the ruler by lending him their support. Hence the interest of Andalusi Umayyads in cultivating good relations with legal-religious elites. ${ }^{12}$

Another fundamental component of the process of legitimation was the representation of military campaigns as jihād against the Christian enemy to extend the domains of faith. This practice established the credentials of Andalusi monarchs as good Muslim rulers, since the pursuit of prestigious actions was one of the means of political legitimation. ${ }^{13}$ This intense military activity between Muslims and Christians in the Iberian Peninsula also produced other forms of

${ }^{11}$ M. Fierro, "Sobre la adopción del título califal por 'Abd al-Raḥmān III al-Nāșir." Sharq al-Andalus 6 (1989): 37-41; eadem, Abdarramán III y el califato omeya de Córdoba (San Sebastian: Nerea, 2011): 17; J. Safran, "The Command of the Faithful in al-Andalus: A Study in the Articulation of Caliphal Legitimacy." International Journal of Middle Eastern Studies 30 (1998): 184; eadem, The Second Umayyad Caliphate: The Articulation of Caliphal Legitimacy in al-Andalus (Cambridge, MA: Harvard University Press, 2000): 119, 190-1. Throughout the history of Islam, diverse regimes appealed to the descendants of the Prophet or to his Arabic ancestors to legitimize themselves through the production of genealogical chains. For example, recent studies examine the genealogy of the Nasrids in the kingdom of Granada; see B. Boloix Gallardo, "The Genealogical Legitimization of the Nașrid Dynasty: The Alleged Anșārī Origins of the Banū Nașr." In The Articulation of Power in Medieval Iberia: 61-85; M. Fierro, "Ways of Connecting with the Past: Genealogies in Nasrid Granada." In Genealogy and Knowledge in Muslim Societies: Understanding the Past, ed. S. BowenSavant and H. de Felipe (Edinburgh: Edinburgh University Press, 2014): 71-88.

12 Fierro, Abdarramán III: 16-8, 29; Safran, "The Command of the Faithful": 194. Regarding the importance of ulemas for the legitimization of rulers, see J.-P. Hartung, "Enacting the Rule of Islam: On courtly patronage of religious scholars in pre- and early modern times." In Court Cultures in the Muslim World. Seventh to Nineteenth Centuries, ed. A. Fuess and J.-P. Hartung (London: Routledge, 2011): 296-325, as well as P. Chalmeta, "Le poids des intellectuels hispano-arabes dans l'évolution politique d'al-Andalus." Cahiers de la Méditerranée 37 (1988): 107-29; H. Monés, "Le rôle des hommes de religion dans l'Histoire de l'Espagne musulmane jusqu'à la fin du califat." Studia Islamica 20 (1964): 84-5.

${ }^{13}$ Fierro, Abdarramán III: 47-65, 76-93; Safran, "The Command of the Faithful": 188-9, 193; eadem, The Second Umayyad Caliphate: 191-3. The jihād also figured among attempts to construct legitimacy in other historical periods in al-Andalus; see A. Krasner Balbale, "Jihād as a Means of Political Legitimization in Thirteenth-Century Sharq al-Andalus." In The Articulation of Power in Medieval Iberia: 87-105. 
legitimation; such is the case of the redemption of captives taken in enemy territory, which offered an additional resource in this regard to several generations of Umayyad sovereigns. ${ }^{14}$

Likewise, to manifest their authority and express their legitimacy, the Umayyads of al-Andalus used the state patronage of architecture: mosques, palaces, recreational estates, bridges, aqueducts and other public establishments aimed at improving the population's quality of life figure in Arabic textual sources. The foundation of congregational mosques was particularly important; there the names of sovereigns were proclaimed and the adherence of their subjects was publicly shown. This circumstance explains the significance of these constructions as a political space and their role as an expression of power. ${ }^{15}$

All this ideological codification made the Umayyad sovereigns seek other ways to manifest their power, and inspire fear and respect. The ritual enactment of public ceremonies, parades and receptions served as a means for transmitting a set of symbols through which power was expressed.16 At the same time, the Umayyads of al-Andalus developed a caliphal ideology by means of public proclamations and propaganda poetry, justifying their actions in order to pursue their claim to govern. ${ }^{17}$ Andalusi Umayyads also sponsored chronicles concerning their kingdoms

\footnotetext{
${ }^{14}$ C. Gómez Rivas, "The Ransom Industry and the Expectation of Refuge on the Western Mediterranean Muslim-Christian Frontier, 1085-1350." In The Articulation of Power in Medieval Iberia: 217-32.

${ }^{15}$ The architecture of the Andalusi Umayyads was an important vehicle for expressing political authority through references to their Syrian roots. An example of this is the decoration of the mihräb with mosaics in the Great Mosque of Cordoba, undertaken by the caliph al-Hakam II al-Mustanșir in imitation of the work performed by his Umayyad ancestors in the mosques of Medina, Damascus and the Dome of the Rock. Another example from the artistic point of view is the mobile minbar, also built under the order of al-Hakam II, in the Cordoban mosque, imitating the minbar of Medina. See M. Fierro, "The movable minbar in Cordoba: how the Umayyads of al-Andalus claimed the inheritance of the Prophet." Jerusalem Studies of Arabic and Islam 33 (2007): 149-68; eadem, Abdarramán III: 21-2. Similarly, the foundation of recreational estates in al-Andalus using Syrian prototypes is considered a legitimizing instrument; see G.D. Anderson, "Identity and the Transplanted Dynasty: The Country Estates of Umayyad Córdoba." Chicago Art Journal 13 (2003): $33-45$.
}

${ }^{16}$ M. Barceló, "El califa patente: el ceremonial omeya de Córdoba o la escenificación del poder." Acta Salmanticensia 81 (1991): 151-173; M. Fierro, "Pompa y ceremonia en los califatos del Occidente islámico (s. II/VIII-IX/XV)." Cuadernos del Cemyr 17 (2009): passim; M. Meouak, "Représentations, emblèmes et signes de la souveraineté politique des Umayyades d'al-Andalus d'après les textes arabes." Acta Orientalia 56 (1995): 78-105; J. Safran, "Ceremony and Submission: The Symbolic Representation and Recognition of Legitimacy in Tenth-Century al-Andalus." Journal of Near Eastern Studies 58 (1999): 191-201; eadem, The Second Umayyad Caliphate: 70-97. Regarding ceremonies and protocols as insignias of other caliphates, see the works by M. Ghrouirgate and M.J. Viguera Molins in the final bibliography.

17 Fierro, Abdarramán III: 144-5; Safran, "Ceremony and Submission": 192, 196; eadem, The Second Umayyad Caliphate: 51-97. For more detailed information in this regard, see E. García Gómez, "La poésie 
as records of their achievements; in these works chroniclers promoted Umayyad monarchs' legitimacy, focussing their accounts on a series of events ranging from military successes to largescale constructions. ${ }^{18}$ Similarly, the coinage developed by the Umayyads of al-Andalus, like that of other dynasties' rulers, helped to solidify their political legitimacy, due to its function as an expression of the sovereign power. ${ }^{19}$

\section{Charity and the process of generating legitimacy in Umayyad al-Andalus}

In Islam charity is often understood as a form of devotion rooted in the belief system inspired by the religion. From this point of view, charitable acts could be the result of sincere religious faith in the hope of divine recompense. This religious dimension does not mean that charity could not be due to other motives. Pious works acquire meaning in accordance with the circumstances that surround each act, and with the historical context within which they fall. In pre-modern Islamic societies, where religion dominated people's perspective, there was no clear distinction between divine piety and social conscience. Any charitable act must, therefore, be approached from a dual perspective: that of the religious world of the donor and that of the ways in which his charitable actions were received and interpreted.

Generosity toward the needy formed part of the principle of good government. Consequently, when defining the attributes of a ruler, Muslim legal experts emphasize some basic prescriptions: on the one hand, the need to defend the faith and preserve sharī'a (this legitimates his power in

politique sous le califat de Cordoue." Revue des Études Islamiques (1949): 5-11; S. Pinckney, "The Qașīdah and the Poetics of Ceremony: Three "Īd Panegyrics to the Cordoban Caliphate." In Languages of Power in Islamic Spain, ed. R. Brann (Ithaca: CDL Press, 1997): 1-48.

18 Fierro, Abdarramán III: 167-72; Safran, The Second Umayyad Caliphate: 111-2. Separate mention should be made of the analysis by G. Martínez-Gros about historical production under the Umayyad aegis as part of the discourse of caliphal legitimacy; he holds that pro-Umayyad authors, influenced by Fatimid ideology, produced esoteric texts to elaborate Umayyad ideology; see L'idéologie omeyyade: la construction de la legitimité du califat de Cordoue (X-XI siècles) (Madrid: Casa de Velázquez, 1992).

${ }^{19}$ See A. Canto García, "El periodo omeya. El Emirato. La aparición de la tipología califal. 'Abd al-Raḥmān III: Sus sucesores." In Actas del I Jarique de Estudios Numismáticos Hispano-Árabes (Saragossa: Institución Fernando el Católico, 1988): 29-41; P. Guichard, “Al-Manșūr ou al-Manșūr bi-Llāh? Les laqab/s des Amirides d'après la numismatique et les documents officiels." Archéologie islamique 5 (1995): 47-53; idem, "Quelques réflexions sur le monnayage des premières taifas andalouses (1009/400-1059/451)." In Actes del II Jarique de Numismàtica Hispano-Àrab (Lérida: Institut d'Estudis Ilerdencs, 1990): 155-161. 
the eyes of the believer) and, on the other, the obligation to guarantee justice for his subjects. These principles act as a foundation for the role of the ruler as a dispenser of charity. ${ }^{20}$

Beneficence might be subject to manipulation for the attainment of political ends, since it could be related to a strategy of legitimation of power. Owing to its considerable potential for engendering legitimacy, charity became a tool for recruiting supporters and, thus, for strengthening the image of rulers as legitimate leaders. ${ }^{21}$ It proved so effective in fact that in some Islamic contexts beneficence actually produced rivalry between the political authorities and other sectors of the population who also practiced it.22 This use of charity for political purposes is documented in al-Andalus, where the Umayyad rulers tried to play up their benefactor role as a legitimizing factor.

${ }^{20}$ El Mansour, "Hospitality, Charity", 183-184. The universalist political discourse in the Islamic tradition advocates that justice and equity are essential for good governance on the basis of the principle that royalty can outlive infidelity, but not injustice; see J. Dakhlia, Le divan des rois. Le politique et le religieux dans l'Islam (Paris: Editions Aubier, 1998): 227-54. This image coincides with features recommended by the Koran and the Sunna, developed later by the "Mirrors for Princes" (nașīhāt al-mulūk), which constitute a genre of court literature on the interrelation between philosophical ethics and government practice, political legitimation being one of its key functions; see S. von Hees, "The Guidance for Kingdoms: Function of a "mirror for princes" at court and its representation of a court." In Court Cultures in the Muslim World: 370-82.

21 This strategy was based on the principle of reciprocity, through which a weak person received gifts from someone stronger and, in compensation, offered him loyalty or some other kind of service; in this way, clientele bonds were reaffirmed. According to M. Mauss, the exchange of gifts between individuals is what creates order and social stability; see The Gift: The Form and Reason for Exchange in Archaic Societies (London: Routledge, 1990): 17-8. In this regard, P. Crone holds that in the Islamic conception social inequality is sanctioned by God, so that men are forced to cooperate with one another to survive; see Medieval Islamic Political Thought (Edinburgh: Edinburgh University Press, 2004): 340-57. M. Bonner, meanwhile, asserts that in early Islam charity had to be understood in relation to leadership, as surplus wealth was used to achieve power; see "Poverty and Charity in the Rise of Islam." In Poverty and Charity in Middle Eastern Contexts, ed. M. Bonner, M. Ener and A. Singer (New York: Suny Press, 2003): 16-8. Concerning bonds between individuals based on loyalty and benefit, R.P. Mottahedeh, Loyalty and Leadership in an Early Islamic Society (Princeton: Princeton University Press, 1980): 72-80.

${ }^{22}$ An illustrative case is the rivalry between Marinid sultans and Sufi shaykhs in the Maghreb, when furnishing charity. With the expansion of Sufism, especially in the $7^{\text {th }}-8^{\text {th }} / 13^{\text {th }}-14^{\text {th }}$ centuries, zāwiyas arose as centres of beneficence and food distribution (iț'àm al-ța'ām). The manipulation of the exercise of charity to perpetuate their hegemony over dependent groups led the sultans to limit the zāwiyas' function as dispensers of beneficence, whilst they improved the role of the government as a provider of welfare. See El Mansour, "Hospitality, Charity": 178, 182-5; F. Rodríguez Mañas, "Charity and Deceit: The Practice of the It'ām al-ta'ām in Moroccan Sufism." Studia Islamica 91 (2000): 59-90. 
Charitable acts performed by powerful individuals tend to be better documented than those carried out by others more modest, since the lives of the former, unlike those of the latter, were reflected in the works of contemporary authors, in many cases under the patronage of the very individuals portrayed in the biographies, as mentioned above. Pious deeds were recorded in writing, as they lent the donors social prestige. Arabic authors often place their emphasis on building up a picture of the ruler and the symbolic representation of institutional power. They stress the juxtaposition of virtues and a charitable inclination. Among the diverse qualities that make up the profile of the ideal ruler, many carry a considerable religious charge. In general, in the Umayyad period in al-Andalus he was represented as an exemplary Muslim: just, generous, charitable, compassionate, merciful, a triumphant warrior for the faith against the Christians, etc. One should remember that political power in Islam is a delegation from God, who is the source of all authority. As the representative of God on earth, it is taken for granted that the ideal Muslim ruler acts in His image, embodying some divine attributes, such as those mentioned here.

Biographical data usually give general information about this charitable tendency and then proceed to illustrate it through specific activities conducted by sovereigns. The present paper explores the ethical portrait of various historical figures, reflecting, amongst other things, how generosity and beneficence were incorporated in biographical accounts as part of the portrayal of ideal lives. ${ }^{23}$

In the light of the collected data from the textual sources that constitute the basis of this study, ${ }^{24}$ we now proceed to make an overall assessment and a detailed analysis of the political use of charity during the Umayyad period in al-Andalus. This use of charity principally adopted three forms: voluntary alms (șadaqa), obligatory alms-giving (zakāt) and the institution of pious endowments (ḥubs, pl. aḥbās; waqf, pl. awqāf). In general, voluntary acts of charity seem to have surpassed payments of zakāt in terms of volume. ${ }^{25}$ In this context, hubs khayrī (public), consisting of donations made in benefit of pious works, deserves special mention. ${ }^{26}$

${ }^{23}$ In general, the lives of pious exemplary individuals were an object of study, since they represented models of conduct and values. For this reason, these same qualities are highlighted in the lives of many ulemas, as it can be appreciated in the Andalusi and North African biographical literature. Though in a strict sense one cannot speak about specific virtues of the rulers, their pious works had a legitimizing force that those of the ulemas did not have. This legitimizing factor was determined, mostly, by the circumstances and the context that surrounded every pious act. See Carballeira Debasa, "Forms and Functions of Charity": 20914; eadem, "Pobres y caridad en al-Andalus", 77-82, 88.

${ }^{24}$ See the summary of Arabic sources at the end of this paper.

25 On alms-giving in al-Andalus, see the works mentioned in note 3.

${ }^{26}$ Regarding the system of ḥubs in al-Andalus, see A.M. Carballeira Debasa, Legados píos y fundaciones familiares en al-Andalus (siglos IV/X-VI/XII) (Madrid: CSIC, 2002); eadem, "The Role of Endowments in the Framework of Andalusian Society." In Stiftungen in Christentum, Judentum und Islam vor der Moderne, ed. M. 


\subsection{Charity from Newly Established Rulers}

The sources consulted reveal that one of the objectives of official charity was to win the favour of the population and gain their sympathy upon the arrival of a new government on the political scene. This modus operandi is attested on various occasions throughout the Umayyad period, although it was not a practice followed systematically by all the rulers.

Upon assuming power, sovereigns would adopt a series of measures that benefitted the population. For example, they might exempt their subjects from payment of taxes, as occurred in $238 \mathrm{AH} / 852 \mathrm{AD}$ at the beginning of the reign of the emir Muhammad I, who released a number of people from their tax obligations. ${ }^{27}$ Likewise, one of the first acts in the reign of 'Abd al-Rahmān III (d. 359 AH/961 AD) was to improve the living conditions of his subjects, suppressing certain taxes that had been introduced under the reign of his predecessor, emir 'Abd Allāh (d. 300 AH/912 AD). ${ }^{28}$

The poor also received alms on the occasion of the investiture of 'Abd al-Rahmān I in 138 AH/756 AD. ${ }^{29}$ Similarly, when the emir 'Abd al-Raḥmān II ascended the throne in 206 AH/822 AD, the chroniclers report that he distributed gala attire among the courtiers, whilst he spent 5,000 dinars in aid of the poor of Cordoba; Arabic authors specify that with these and other measures he won the affection of both the nobility and the people. ${ }^{30}$ So not only the needy benefitted from this generosity, but also members of the court; it is significant for the purposes of this study that with such measures this sovereign sought to garner for his cause the support of all social strata, not excluding members of the Andalusi elite. Despite the brevity of his reign, the emir al-Mundhir (d. $275 \mathrm{AH} / 888 \mathrm{AD}$ ) is also remembered for his generosity; 31 in fact, it is particularly recorded that, after being sworn in, he distributed money among the people. ${ }^{32}$ In the same vein, no sooner had al-Hakam II ascended to the caliphate in $350 \mathrm{AH} / 976 \mathrm{AD}$ than he provided aid to the destitute, delivering 100,000 dinars in alms to settle people's debts and redeem captives. ${ }^{33}$

Borgolte (Berlin: Akademie Verlag, 2005): 109-21; A. García Sanjuán, Hasta que Dios herede la tierra. Los bienes habices en Al-Andalus (siglos X-XV) (Huelva: Universidad de Huelva, 2002); idem, Till God Inherits the Earth. Islamic Pious Endowments in al-Andalus (9-15th Centuries) (Leiden: Brill, 2007).

${ }^{27}$ Muqtabis II/2: ed. 106.

${ }^{28}$ Nafh, I: ed. 354, trans. I, 134.

${ }^{29}$ Dhikr: ed. 119, trans. 127.

${ }^{30}$ Dhikr: ed. 139, trans. 147.

${ }^{31}$ Kāmil, VII: ed. 435, trans. 263.

32 Dhikr: ed. 150, trans. 159.

${ }^{33}$ Dhikr: ed. 170, trans. 180. The responsibility of the ruler toward insolvents and the redemption of coreligionists were two merits that the Arabic sources praise, as well as the care of travellers and the manumission of slaves. With regard to the redemption of captives by the caliph al-Mustanșir, after the 


\subsection{Charity from Established Rulers}

Benevolence was also exercised as a key strategy to increase and consolidate the political power of the reigning emir, as well as to obtain popular support for his successor. The distribution of alms to the multitude in the public appearances of the sovereigns served to demonstrate the munificence of the dynasty. ${ }^{34}$ One illustrative case occurred on Monday 2 shawwāl in 364 AH/15 June $975 \mathrm{AD}$, when the caliph al-Ḥakam II, accompanied by his heir Hishām, ordered the distribution of alms among the poor, presiding over the event from the rooftop of the citadel of Cordoba in the midst of a popular clamour. The chronicler mentions that assistance from this sovereign reached everyone and that, for their part, the people's voices were raised in blessing. 35 Although there was actually scarcely any contact between the two donors and the crowd of beneficiaries, the performance made the monarch visible and close to his subjects. Of no less significance is the active role played by the recipients of the alms, singing praises as a gesture of approval toward the Umayyad regime. This mise en scène should be interpreted as a symbol of the continuity of the dynastic legitimacy that the caliph, old and infirm, sought for his future successor, whose eligibility to govern would presumably have been in question as a result of his young age. 36 It is, then, an act with a clearly propagandistic design. This event in favour of the prince heir actually formed part of a well-designed programme to politically legitimate Hishām. ${ }^{37}$

military triumphs obtained by his predecessor 'Abd al-Raḥmān III, there must have only remained few or no Muslim prisoners in Christian hands; perhaps this was a symbolic measure taken because of the prestige value it entailed, as mentioned above; see F. Vidal Castro, "Los cautivos en al-Andalus durante el Califato Omeya de Córdoba: aspectos jurídicos, sociales y económicos." Miscelánea de Estudios Árabes y Hebraicos. Sección Árabe-Islam 57 (2008): 360.

${ }^{34}$ Over the same period, the Fatimids were acting similarly; see H. Halm, The Empire of the Mahdi: the Rise of the Fatimids, trans. M. Bonner (Leiden: Brill, 1996): 111, 199, 233, 316, 355-7, 365, 372. The growing importance of charity among Middle Eastern ruling elites, especially from the $6^{\text {th }}-7^{\text {th }} / 12^{\text {th }}-13^{\text {th }}$ centuries onwards, can be understood as a consequence of the adoption of the Sultanate model; see A.M. Eddé, Saladin, trans. J.M. Todd (Cambridge, MA: Harvard University Press, 2011). It also could be seen as the imposition of new cultural and religious patterns and institutions (what G. Makdisi once called «Sunni revival»); see G. Makdisi, History and Politics in Eleventh-Century Baghdad (Aldershot: Variorum, 1990).

${ }^{35}$ Muqtabis VII: ed. 233-4, trans. 275-6.

${ }^{36}$ As is well-known, Islamic legal doctrine did not allow a minor to govern. Concerning the majority of age in Islamic legal doctrine, see A. Zomeño, "En los límites de la juventud: niñez, pubertad y madurez en el derecho islámico medieval." Mélanges de la Casa de Velázquez 31 (2004): 85-98.

37 The Umayyad regime undertook a series of measures with a great display of propagandistic activity aimed at presenting prince Hishām as the legitimate heir; see A. García Sanjuán, "Legalidad islámica y legitimidad política en el Califato de Córdoba: la proclamación de Hišām II." Al-Qanțara 29 (2008): 45-77. 
Further evidence of other charitable acts also lent special relevance to the figure of Hishām. This is borne out by the charity distributed by al-Hakam II, who in 361 AH/972 AD had given a considerable sum of money for the needy and travellers as an expression of blessing to God for the good dispositions manifested by his only son. ${ }^{38}$ Similarly, in 363 AH/974 AD, during the prince's attack of smallpox, the monarch requested divine intervention in the process for the remission of evil. When the youth was cured, a reception was offered to high court officials and large sums of money were handed out as alms to the poor in thanksgiving to God for the favour bestowed; ${ }^{39}$ such concern, emphasized by the reception offered by the sovereign to celebrate the recovery of Hishām's health, highlighted the prince's status as heir and served as a prologue to his later official presentation before the court as the caliph's successor. Thus, the monarch's aim was to spread a particular conception of political power that would create a virtual bond with the population, with all the social groups. The idea was for his subjects to develop feelings of loyalty and respect for their rulers, who projected a kind of paternal image with their charitable behaviours.

\subsection{Charity and Circumcision}

In the medieval Islamic world the occasion of a son's circumcision frequently provided another opportunity for the ruler to behave in a benevolent manner. ${ }^{40}$ Indeed, this ritual act could include a good number of children, both of members of the elite and of impoverished families. During the Umayyad period in al-Andalus only one case is documented in this regard, involving Muhammad Ibn Abī 'Āmir, later known as al-Manșūr, the famous chamberlain of the caliph Hishām II (r. 366$403 \mathrm{AH} / 976-1013 \mathrm{AD}$ ). He is said to have given orders to circumcise his sons, 500 other boy children of his courtiers and many poor children, all of which cost him 500,000 gold pieces. ${ }^{41}$

38 Muqtabis VII: ed. 77, trans. 275-6.

39 Muqtabis VII: ed. 233-4, trans. 275-6. In other pre-modern Islamic societies (Fatimids, Ayyubids, Mamluks, Ottomans) rulers resorted to charity during sickness as an instrument for seeking divine help and, after recovery, as a token of gratitude to God. See El Mansour, "Hospitality, Charity": 188; M. Hoexter, "Charity, the Poor, and Distribution of Alms in Ottoman Algiers." In Poverty and Charity in Middle Eastern Contexts: 145-63; Y. Lev, Charity, Endowments, and Charitable Institutions (Gainesville: University Press of Florida, 2005): 23-5; A. Sabra, Poverty and Charity in Medieval Islam: Mamluk Egypt, 1250-1517 (Cambridge: Cambridge University Press, 2000): 57-8; A. Singer, Charity in Islamic Societies (Cambridge: Cambridge University Press, 2008): 86-8.

${ }^{40}$ It is possible to find examples of such events in the Sa'di Maghreb, Mamluk Egypt and Ottoman Empire; see El Mansour, "Hospitality, Charity": 188; Sabra, Poverty and Charity: 54; Singer, Charity in Islamic Societies: 82.

${ }^{41}$ Nihāyat, I: ed. 66-7, trans. 60-1. 
This event seems to have been unique in the Andalusi context, and it is significant that it was ordered by someone with aspirations to power whose legitimacy was questionable. As is wellknown, Ibn Abì 'Āmir took advantage of the tender age of the monarch to supersede him in power and to usurp his prerogatives. For this reason, he could not justify his own government in dynastic terms, which meant he was obliged to legitimate his political mandate in the eyes of his coreligionists. ${ }^{42}$ This event unquestionably represented a demonstration of power and prestige that reminded the participants, from all the social strata, of their dependence on the political authority. One must not overlook that, in an Islamic context, circumcision had a symbolic meaning for the boy and his father. For the former it symbolized the transition from childhood to adulthood, whilst it was the progenitor who, as such, shouldered the responsibility for organizing the event. Ibn Abī 'Āmir may have appropriated the paternal symbolism of the circumcision in his own power strategy.

\subsection{Charity and Education}

The population's cultural formation was a factor that must be taken into consideration. The sources contain descriptions of some beneficent acts performed by al-Hakam II and devoted to activities that reinforced study and education, these latter both values that are fundamental in Islam. In an account dated in the year $356 \mathrm{AH} / 967 \mathrm{AD}$ there is evidence that teachers were designated to teach the Koran to poor children in Cordoba; for this task three schools were founded in the area of the Great Mosque and twenty-four in the surroundings of the capital. 43 Another anecdote makes allusion to a pious endowment established in 364 AH/975 AD by the caliph for the purpose of meeting the costs of the wages of those teachers. ${ }^{44}$

The teaching of the Koran to Muslim children, rich and poor alike, was an instrument for the learning of Islam and for the defence of faith. This religion offered a spiritual order for the world,

42 To promote his popularity, Muhammad Ibn Abī 'Āmir followed the model of the Umayyad caliphs by continuing with their policies. The sources not only reflect that he included charitable deeds, but also that he exploited the importance of jihād and of military success, as well as the state patronage of architecture, the implementation of protocol and vigilance of purity of the faith. See Safran, The Second Umayyad Caliphate: 98-108. Concerning the characterization of al-Manșūr, see the works by X. Ballestín, L. Bariani, A. Echevarría, V. Martínez-A. Torremocha, C. de la Puente and P. Sénac in the final bibliography. Apart from this paradigmatic case, there is less information regarding the charitable virtues of the rest of the courtiers; overshadowed by sovereigns, these individuals did not actually need to attain the same degree of legitimization that the chamberlain of Hishām II sought in his exercise of power. In general, pious acts performed by al-Manșūr, in addition to serving his own interests, formed part of the identifying signs of the liberality of the rulers.

43 Bayān II: ed. 240, trans. 397.

${ }^{44}$ Bayān II: ed. 249, trans. 411; Muqtabis VII: ed. 207, trans. 247. 
along with a legal and political framework. Hence by facilitating the study of the Koranic text from childhood, rulers promoted acceptance of the existing order of things. ${ }^{45}$

\subsection{Charity and Religious Devotions}

Sometimes, acts with a clear religious content do not obscure the political motivations of donors. This is the case, for instance, with the charitable donations of certain Andalusi rulers during the celebration of religious festivities. Although the Islamic calendar is marked by diverse occasions for dispensing beneficence, in the period under study there exist references only to the charity practiced by al-Hakam II. Every year, on occasion of the festivities for the month of Ramadan, he distributed alms among the poor, the surplus being given out to travellers. ${ }^{46}$ Through this action, the caliph drew close to God and aroused the religious spirit of the recipients of charity; additionally, the symbolism of such acts identified the monarch with the sacred calendar.

The same could be said about other cases of the distribution of alms for the purpose of political legitimation, such as those related to expiation of a religious transgression by rulers. Alms distribution occurred, for example, when 'Abd al-Raḥmān II and al-Ḥakam II confess their repentance for having intimate relations with some of their concubines during the month of Ramadan. ${ }^{47}$

${ }^{45}$ Concerning the importance of the link that existed between charity and education, see Lev, Charity, Endowments: 85-112; M. Shatzmiller, "Royal Waqf in 14th-century Fez." Anaquel de Estudios Árabes 2 (1991): 193-217; Singer, Charity in Islamic Societies: 82-5. For the process of learning and the social function of education, see also the works by M. Chamberlain, Knowledge and Social Practice in Medieval Damascus, 1190-1350 (Cambridge: Cambridge University Press, 1994); D. Ephrat, Learned Society in a Period of Transition (New York: State University of New York Press, 2000).

${ }^{46}$ Muqtabis VII: ed. 23, 76, 110, 226, trans. 47, 98, 140, 268. Charitable acts within the framework of religious festivities in the Islamic calendar were not exclusive to the Andalusi Umayyad period. In the Maghreb, for instance, the Marinid sultans adopted the celebration of the birth of the Prophet (mawlid) as their main religious festival; see J.A.O.C. Brown, “Azafid Ceuta, Mawlid al-Nabī and the Development of Marinid Strategies of Legitimization." In The Articulation of Power in Medieval Iberia: 127-51. The Nasrids of al-Andalus used patronage of the mawlid for their benefit too, but, unlike the Marinids, they did not successfully integrate it in their power rituals; see C. Robinson and A. Zomeño, "On Muhammad V, Ibn alKhațīb and Sufism." In The Articulation of Power in Medieval Iberia: 153-74.

47 This question has been analysed by M. Fierro, "Caliphal Legitimacy and Expiation in al-Andalus." In Islamic Legal Interpretation. Muftis and Their Fatwas, ed. M.K. Masud, B. Messick y D.S. Powers (Cambridge: Harvard University Press, 1996): 55-63. 
Similarly, the emir Hishām I (d. 180 AH/796 AD) used to send bags full of money to mosques, so that the sum could be distributed among those who frequented these sacred places on dark rainy nights. ${ }^{48}$ Thus, the emir sought to associate himself with the sacral authority of these places.

It is important to mention here the enlargement of the Great Mosque of Cordoba by al-Hakam II. When the construction work was finished in the year $355 \mathrm{AH} / 966 \mathrm{AD}$, the caliph, in recognition of the favour that God had granted him, established a hubs to aid the destitute in the frontier provinces; as the sole exception to this provision, he stipulated that, in the event of famines in Cordoba, the capital should make use of these resources until the situation improved. Another measure adopted by al-Mustanșir as an ostensible token of his gratitude to God consisted of freeing all male slaves of his who had been acquired through a contract of sale. ${ }^{49}$ On one hand, expanding the Great Mosque of Cordoba, as a highly symbolical building, certainly further strengthened the role of al-Hakam II as guardian of the faith; on the other hand, his pious deeds upon termination of the construction underscored the sacred nature of the Umayyad caliphate, transmitting this idea to the recipients of alms. This reinforced the bonds of loyalty between the caliph and his subjects. ${ }^{50}$

\subsection{Charity and Social Justice}

Closely related to charity was the ideologically charged idea of justice as a necessary virtue of a ruler and as a legitimizing factor. According to our historical and biographical sources, this was a moral quality common to various Umayyad monarchs of al-Andalus. Within the broader concept of justice, social justice held a prominent place -the conviction that the population had the right to basic subsistence and to freedom against abuse. The sources contain explicit references to the population's expectations of their rulers' role in intervening to correct abuses or to solve supply shortages.

Concerning the redress of abuses, the historical sources claim that 'Abd al-Rahmān I was generous and maintained a high standard of justice. ${ }^{11}$ His successor, Hishām I, is said to have been

${ }^{48}$ Akhbār: ed. 120-1, trans. 11; Dhikr: ed. 120, trans. 128; Naf̣, I: 334-8, trans. I, 102.

${ }^{49}$ Bayān II: ed. 234, trans. 386-7.

50 Still other pious gestures were attributed to Umayyad rulers in al-Andalus, such as visiting the sick and reciting religious formulas in the ritual for the deceased, due to the religious connotations these actions involved; see Nihāyat, I: ed. 25, trans. 23. On other forms of sacralizing power in Islam, see J. Dakhlia, "Du sacré duel au sacré débattu: la légitimité en écho des souverains maghrébins." Al-Qanțara 17 (1996): 34174.

${ }^{51}$ Kāmil, VI: ed. 111, trans. 136; Mu'jib: ed. 11, trans. 13. 
inclined to justice towards the poor against the rich and the weak against the powerful.52 Similarly, some texts report that the emir al-Hakam I (d. 206 AH/822 AD) had in his entourage a group of people in his trust who kept him informed of people's needs, enabling him to prevent or repair injustices. ${ }^{53}$ With regard to Muhammad I, Muslim authors suggest that he did not tolerate injustice. ${ }^{54}$ Finally, the information concerning the emir 'Abd Allāh is more detailed; he was said to be charitable, since he gave orders for the distribution of provisions among the destitute, who came to him seeking assistance and relief. ${ }^{55} \mathrm{He}$ also personally dispensed justice at the request of his subjects, who had direct access to his presence; in fact, he was accessible both to the powerful and the humble to such a degree that on certain days he used to sit at some of the citadel doors, where cases of injustice were presented to him. ${ }^{56}$

The idea of the just claims of the poor on the wealth of the rich is fundamental in Islamic thought, and this applied all the more in times of food shortages. The appropriate use of wealth by rulers was an inseparable aspect of beneficence. In this regard, the charitable gestures adopted by some Umayyad rulers in order to attenuate the suffering of the population during the shortages are especially illustrative; 57 this attitude was sometimes praised by court poets. Nevertheless, one must mention that, while various famines have been recorded in almost all the kingdoms, the benevolence of rulers toward those affected is not always attested. Only on few occasions is such action documented, as are the cases of al-Ḥakam I, 'Abd al-Raḥmān II, 'Abd al-Raḥmān III, alḤakam II and al-Manșūr.

Concerning the reign of al-Hakam I, his charitable disposition became apparently evident during a severe famine that occurred in 197 AH/812-3 AD. On this occasion the sovereign distributed large sums of money in order to aid the needy and travellers. The emir's virtuous conduct in such unfavourable circumstances was celebrated by the poet 'Abbās b. Nāṣih al-Jazarī in the following panegyric verses:

They were bad times, but their days were safe

${ }^{52}$ Akhbār: ed. 121, trans. 110; Mu'jib: ed. 12, trans. 14; Dhikr: ed. 120, trans. 128.

${ }^{53}$ Kāmil, VI: ed. 378, trans. 195; Nihāyat, I: ed. 41, trans. 36.

${ }^{54}$ Fath: ed. 113, trans. 100.

55 Bayān II: ed. 152, trans. 253; Muqtabis III: ed. 33-4.

56 Mukhtașar: ed. 153, trans. 116-7; Dhikr: ed. 154, trans. 163. The personal intervention of the emir in the field of justice was maintained during the $2^{\text {th }}-3^{\text {th }} / 8^{\text {th }}-9^{\text {th }}$ centuries until Islamic law eventually attained normative force; see C. Müller, "Redressing injustice: Mazāllim jurisdictions at the Umayyad court of Córdoba (eighth-eleventh centuries CE).” In Court Cultures in the Muslim World: 93-104.

57 Such initiatives are also documented in other areas of the Islamic world, such as Ayyubid and Mamluk Egypt; see Lev, Charity, Endowments: 134-6; Sabra, Poverty and Charity: 134-68. 
from hardship under his aegis;

fortune was to bring poverty, but that calamity

was dispelled by his abundant generosity. ${ }^{58}$

The attitude of his successor, 'Abd al-Rahmmān II, is described in a similar tone. When a plague of locusts damaged the crops in al-Andalus in $207 \mathrm{AH} / 822 \mathrm{AD}$ setting off a terrible shortage, this monarch was said to have distributed food among the needy of the Umayyad capital. ${ }^{59}$

Later, in $303 \mathrm{AH} / 915 \mathrm{AD}$, at the time of the severe famine that affected Andalusi territory, 'Abd al-Rahmmān III is said to have given out countless alms to the destitute. ${ }^{60}$ It is also recorded that during the drought of $323 \mathrm{AH} / 936 \mathrm{AD}$ al-Nāṣir played a crucial role in preventing a socioeconomic crisis, because at his behest foodstuffs were brought to al-Andalus from other places. ${ }^{61}$

The caliph al-Hakam II also proved prolific in his pious deeds in the context of the food crises that took place in the Umayyad period. His intervention is documented on two occasions. As a result of the intense famine that ravaged Cordoba in the year $353 \mathrm{AH} / 964 \mathrm{AD}$, al-Mustanșir provided food to the indigent people of the city, to those on the outskirts and to al-Zahrā'.62 During another later shortage in 358 AH/968-69 AD the caliph gave the order to hand out 12,000 loaves of bread among the needy of Cordoba on a daily basis until the previous state of prosperity was re-established. ${ }^{63}$

Likewise, regarding the reign of Hishām II, the sources consulted reveal that, in response to a terrible famine in $379 \mathrm{AH}$ /989-90 AD, his chamberlain al-Manșūr ordered the production of 22,000 loaves of bread per day to feed the hungry, exempted subjects from tithes and shrouded the dead, behaving as no king had done until that time.64 It has already been noted that Muhammad Ibn Abī 'Āmir appropriated the caliphs' resources of legitimation, pious deeds amongst them. As a result, Muslim authors equated his behaviour with that of a sovereign, clearly bestowing him with political legitimacy.

${ }^{58}$ Dhikr: ed. 131, trans. 139; Muqtabis II/1: ed. 92, trans. 12; Nihāyat, I: ed. 37, trans. 32.

${ }^{59}$ Kāmil, VI: ed. 384, trans. 198; Muqtabis II/2: 93; Nihāyat, I: ed. 42, trans. 38.

${ }^{60}$ Mukhtașar: ed. 167-8, trans. 139; Bayān II: ed. 166-8, trans. 276-9; Muqtabis V: ed. 103-4, 109-10, 124 , trans. 88, 92, 104.

${ }^{61}$ Muqtabis V: ed. 383-4, trans. 287.

${ }^{62}$ Bayān II: ed. 236, trans. 389.

${ }^{63}$ Dhikr: ed. 173, trans. 183.

${ }^{64}$ Dhikr: ed. 181-2, trans. 193. 
As indicated above, among the measures adopted to alleviate an existing critical shortage, food distribution ${ }^{65}$ occupied a prominent position and, to a lesser degree, the distribution of money and the exemption of tax payment. In the case of the exemption of payment of the tithe stipulated by al-Manșūr, it is related to the fair distribution of zakăt during his mandate. In this regard, Arabic texts relate that this tax was handed out to the needy in each locality, whilst the rulers took nothing from it, excepting funds for the government and armies. ${ }^{66}$ Another government distinguished for its low tax levy was that of Hishām I, who is praised for not imposing on his Muslim subjects any tax other than the zakăt or the tithe prescribed by the Koran and the Sunna. ${ }^{67}$ The complimentary remarks offered by Arabic authors regarding the just conduct of both rulers contrast with the criticism received by Muhammad I, owing to his refusal to exempt the population from paying the tithe in a period of famine. Indeed, even the dynasty's official chronicler, Ibn Hayyān, notes the monarch's lack of generosity before the misfortunes of others in a serious situation that demanded his attention; this occurred during the famine that took place in 260 $\mathrm{AH} / 873 \mathrm{AD}$ as a consequence of the bad harvests. On that occasion the person in charge of collecting the tithe requested of the emir that he relieved his subjects of payment of the tribute. But Muhammad I not only disregarded his pleas in this regard, but designated someone else in his place to collect half of the tithe with unyielding zeal. This intransigent posture on the part of the monarch led to people dying of starvation and elicited a clamour of complaints from the populace, which infuriated the emir. ${ }^{68}$

\section{Concluding remarks}

65 The provision of food has a long tradition in Islam; indeed, in Koran 107 it appears as a fundamental form of assistance. In the chronological period covered by this work the greater part of the urban population of al-Andalus lived below the poverty line at the level of subsistence. Bread was, in consequence, the main foodstuff; this is, at least, what some of the alms distributed by al-Ḥakam II and al-Manșūr indicates. This practice is also documented in other Islamic contexts (Ayyubids and Mamluks); see M.H. Reid, Law and Piety in Medieval Islam (Cambridge: Cambridge University Press, 2013): 97-143.

66 Mudhakkirāt: ed. 17, trans. 83.

${ }^{66}$ Dhikr: ed. 195, trans. 205.

${ }^{67}$ Nafh, I: ed. 338, trans. I, 102.

${ }^{68}$ Muqtabis II/2: ed. 172-3. In al-Andalus and beyond Andalusi territory (Ottomans) mechanisms were applied to alleviate bad crop years; see I. Camarero Castellano, Sobre el "estado de ŷā'iha": Teoría y práctica jurídica de la calamidad rural y urbana en Al-Andalus (ss. VIII-XV) (Sevilla: Universidad de Sevilla, 2015); Singer, Charity in Islamic Societies: 164. 
As we have been able to verify over the course of this article, during the Umayyad period in alAndalus charity seems to have been an important element in the construction of the identity of a virtuous ruler. Some chroniclers refer to the magnanimity of sovereigns as one of the components in the list of their merits, around which a good part of their official image is built; these merits constitute a set of moral virtues, in which charity and compassion stand out. The biographical accounts often reflect pious deeds as a sign of generosity and an absence of oppression. Of course, as works composed towards the furtherance of certain political and ideological goals, these historical and biographical accounts frequently exploit the idea of benevolence as a political tool; sometimes this use is mentioned explicitly in the texts and other times it is implied by the context. Thus, the beneficence of some monarchs was expressed through money and food for the poor, the establishment of pious endowments in favour of the needy, as well as the founding of religious and public buildings. But sometimes charity dispensed by the political authority came in association with other pious works, such as exemption from taxes, assumption of the debt payments of insolvent individuals, redemption of Muslim captives, freeing of slaves, hospitality toward travellers, visits to the sick, attitudes of piety toward the deceased, etc. These practices often signified not only religious piety, but also prestige, authority and power, and consequently took on a prominent political dimension as sources of a government's legitimation. Hence charity offered to the monarch the occasion to obtain salvation as a Muslim and to exercise justice as a sovereign.

The Umayyad rulers of al-Andalus exercised political power by means of a series of strategies and propagandistic resources to acquire legitimacy. The present study has explored the use of charity as a form of interpersonal relation between the individual exercising political power and those who were subject to him. One of the fundamental functions of benevolence was to present an image of proximity between the sovereign and his subjects. A reciprocal relationship was, thereby, set up between both parties. The ruler's solicitude for those he governed and their expected loyalty by way of gratitude toward him were crucial for the cultivation of the popular support of subordinate social groups. Beneficence could, therefore, be used at the service of an ideology to bolster the reputation of the donor and, thus, legitimate the government. From this perspective, charity is conceived as a tool for gaining recognition in political and social life. So the beneficence practiced by rulers not only sought to provide basic subsistence, but also to preserve the existing socio-economic order.

The use of charity for political and social purposes fits into a wider model of the employment of religion in pre-modern Islamic societies. According to this model, government and social order were presented as being inspired by religion. The Umayyad rulers of al-Andalus could exhibit their benevolence within a religious scenario to make its impact more powerful. Hence manifestations of generosity were included into the rhythms of the Islamic calendar as a part of religious 
festivities. This perception of charity as sacred and transcendent also served to sacralise the figure who wielded political authority.

The beneficence shown by members of the ruling elite must be considered in the light of the responsibilities and expectations of status. Institutional power was supposed to exercise social responsibility, since the rulers were expected, to some degree, to promote charity and justice among their subjects. ${ }^{69}$ Through the performance of charitable deeds, political authorities justified their position in society as the benefactors of the most unfortunate. So the distribution of resources added another level to the political dimension of beneficence, symbolizing the ruler's capacity to guarantee the material welfare of the population. It is interesting to note that the concentration of power in the Umayyad capital, Cordoba, also brought more charitable acts to that city.

At this point, how should we interpret the fact that not all the Umayyad rulers of al-Andalus approached charity in the same way? The information contained in the Arabic sources emphasises the role of some of them as distributors of beneficence. In particular, charitable virtues take on special prominence in the figure of al-Hakam II. His father and predecessor, 'Abd al-Rahmān III, had availed himself of his military and political credentials as the basis for his proclamation as caliph. With these elements as support, his legitimacy was well consolidated, with no special need to resort to an impressive display of charity. Al-Mustanșir inherited, in contrast, a kingdom at peace within and beyond its frontiers, so he had no opportunity to exhibit his politico-military talents as his progenitor had done. It is quite likely that al-Mustanșir felt compelled to employ other strategies, especially because he was late in fathering a son, and undertook a campaign of legitimation to justify the accession of his heir at a young age. A chronological examination of the charitable gestures of al-Hakam II reveals a greater number of references to such activity following the birth of prince Hishām in $354 \mathrm{AH} / 965 \mathrm{AD}$, which could be interpreted as a strategy aimed at leaving no loose ends to his succession. Nevertheless, one should not overlook the fact that al-Mustansirir had a leaning toward beneficence, as revealed by the existence of pious deeds prior to that date.

Bearing all these aspects in mind, one should consider whether Arabic sources present a genuine or idealized portrait of the donors. I suggest that in many cases Muslim authors resorted to historiographical stereotypes that are repeated biography after biography. Nevertheless, sometimes they also introduced a certain amount of individualized biographical description, as occurs with the misconduct of emir Muhammad I. Whatever the case, it is possible to acquire

${ }^{69}$ Concerning the limits of the function of authority in Islam, see C. Imber, Ebu's-Su'ud: The Islamic Legal Tradition (Edinburgh: Edinburgh University Press, 1997): 79-94, 156-62; B. Lewis, The Political Language of Islam (Chicago: The University of Chicago Press, 1988): 43-70. 
reliable understanding of legitimation, as many of these sources had a legitimizing or eulogizing function and reflected what the authors believed was the role of a good monarch at that time. In consequence, they stand as a valuable source regarding the culture of the charity in the society in which such biographical portraits were created.

\section{ARABIC SOURCES}

Mudhakkirāt: 'Abd Allāh b. Bulughghīn. 1955. Min mudhakkirāt al-amīr 'Abd Allāh ākhar mulūk Banī Zīrī bi-Gharnāța al-musammāt bi-Kitāb al-Tibyān, ed. Évariste Lévi-Provençal. Cairo: Dār al-Ma‘ārif; trans. Évariste Lévi-Provençal and Emilio García Gómez. 1981. El siglo XI en primera persona. Las "memorias" de 'Abd Allāh, último rey zīrí de Granada, destronado por los almorávides (1090). Madrid: Alianza Editorial.

Mu'jib: 'Abd al-Wāḥid al-Marrākushī. 1847. Kitāb al-Mu'jib fi talkhịs akhbār al-Maghrib, ed. Reinhart Dozy. The history of the Almohades, preceded by a sketch of the history of Spain, from the times of the conquest till the reign of Yusof ibn-Táshifin, and of the history of the Almoravides. Leiden: Oriental Press; trans. Ambrosio Huici Miranda. 1955. Lo admirable en el resumen de las noticias del Magrib. Tetouan: Editora marroquí.

Akhbār: $\quad$ 1867. Akhbār majmū'a (Colección de tradiciones). Crónica anónima del siglo XI, dada a luz por primera vez, ed. and trans. Emilio Lafuente y Alcántara. Madrid: RAH.

Mukhtașar: 'Arīb b. Sa'īd. 1948-1951. Mukhtașar Ta'rīkh al-Tabarī, ed. Georges S. Colin and Évariste Lévi-Provençal, Al-Bayān al-mughrib. Leiden: Brill; trans. Juan Castilla. 1992. La crónica de 'Arīb sobre al-Andalus. Granada: Impredisur.

Dhikr: $\quad$ 1983. Dhikr bilād al-Andalus. Una descripción anónima de al-Andalus, ed. and trans. Luis Molina. Madrid: Instituto "Miguel Asín”. 2 vols.

Fath: $\quad$ 2002. Fath al-Andalus, ed. Luis Molina. Madrid: CSIC; trans. Mayte Penelas. 2002. La Conquista de al-Andalus. Madrid: CSIC.

Kāmil: $\quad$ Ibn al-Athīr. 1965-1967. Al-Kāmil fĩ al-ta'rīkh, ed. Carl J. Tornberg. Beirut: Dār Șādir. 13 vols.; partial trans. Edmond Fagnan. 1898. Annales du Maghreb \& de l'Espagne. Algiers: Typographie A. Jourdan.

Muqtabis II/1: Ibn Ḥayyān. 2003. Muqtabis II. Anales de los Emires de Córdoba Alhaquém I (180206 H./796-822 J.C.) y Abderramán II (206-232/822-847), ed. Maḥmūd 'A. Makkī. AlSifr al-thānī min Kitāb al-Muqtabas. Riad: Markaz al-Malik Fayṣal li-al-buhūth waal-dirāsāt al-islāmiyya; trans. Maḥmūd 'A. Makkī and Federico Corriente. 2001. 
Crónica de los emires Alhakam I y 'Abdarrahman II entre los años 796 y 847 [Almuqtabis II-I]. Saragossa: Instituto de Estudios Islámicos y del Oriente Próximo. Muqtabis II/2: Ibn Ḥayyān. 1973. Al-Muqtabis min anbā' ahl al-Andalus, ed. Maḥmūd 'A. Makkī. Beirut: Dār al-Kitāb al-'Arabī.

Muqtabis III: Ibn Ḥayyān. 1937. Al-Qism al-thālith min Kitāb al-Muqtabis, ed. Melchor Martínez Antuña. Paris: Librairie Orientale Paul Geuthner.

Muqtabis V: Ibn Ḥayyān. 1979. Al-Muqtabas V, ed. Pedro Chalmeta, Federico Corriente and Mahmud Sobh. Madrid: IHAC; trans. María Jesús Viguera and Federico Corriente. 1981. Crónica del califa 'Abdarraḥman III an-Nāṣir entre los años 912 y 942. Saragossa: Anubar-IHAC.

Muqtabis VII: Ibn Ḥayyān. 1983. Al-Muqtabis fĩ akhbār balad al-Andalus, ed. 'Abd al-Raḥmān 'A. al-Ḥajjī. Beirut: Dār al-Thaqāfa; trans. Emilio García Gómez. 1967. El Califato de Córdoba en el "Muqtabis" de Ibn Hayyān. Anales palatinos del califa de Córdoba alHakam II, por 'İsā Ibn Ahmad al-Rāzī (360-364 H. = 971-975 J.C.). Madrid: Sociedad de Estudios y Publicaciones.

Bayān II: Ibn 'Idhārī al-Marrākushī. 1951. Al-Bayān al-mughrib fĩ akhbār al-Andalus wa-alMaghrib, ed. Georges S. Colin and Évariste Lévi-Provençal. Leiden: Brill. Vol. II; trans. Edmond Fagnan. 1904. Histoire de l'Afrique et de l'Espagne intitulée AlBayano'l-Mogrib. Algiers: Alger Fontana. Vol. II.

Nafḥ: $\quad$ Al-Maqqarī. 1968. Naf̣h al-țīb min ghuṣn al-Andalus al-rațīb, ed. Iḥān 'Abbās. Beirut: Dār Șādir. 8 vols.; partial trans. Pascual de Gayangos. 1840. The History of the Mohammedan Dynasties in Spain. London: Oriental Translation Fund of Great Britain and Ireland. 2 vols.

Nihāyat: $\quad$ Al-Nuwayrī. 1917. Nihāyat al-'arab fì funūn al-adab, ed. and trans. Mariano Gaspar Remiro. Historia de los musulmanes de España y África por En-Nuguairí. Granada: Tipografía de "El Defensor".

\section{BIBLIOGRAPHY}

Anderson, Glaire D. 2003. Identity and the Transplanted Dynasty: The Country Estates of Umayyad Córdoba. Chicago Art Journal 13: 33-45.

Ballestín, Xavier. 2004a. Almansor: l'exercici del poder a l'Occident musulmà medieval. Barcelona: Universidad de Barcelona. 
2004b. Al-Mansur y la dawla 'amiriya. Una dinámica de poder y legitimidad en el occidente musulmán medieval. Barcelona: Edicions de la Universitat de Barcelona.

Barceló, Miquel. 1991. El califa patente: el ceremonial omeya de Córdoba o la escenificación del poder. Acta Salmanticensia 81: 51-71.

Bariani, Laura. 2003. Almanzor. San Sebastian: Nerea.

Bennison, Amira K. ed. 2014. The Articulation of Power in Medieval Iberia and the Maghrib. Oxford: Oxford University Press.

Boloix Gallardo, Bárbara. 2014. The Genealogical Legitimization of the Nașrid Dynasty: The Alleged Anșārī Origins of the Banū Nașr. In The Articulation of Power in Medieval Iberia and the Maghrib, ed. Amira K. Bennison. Oxford: Oxford University Press: 61-85.

Bonner, Michael. 2003. Poverty and Charity in the Rise of Islam. In Poverty and Charity in Middle Eastern Contexts, ed. Michael Bonner, Mine Ener and Amy Singer. New York: Suny Press: 16-8.

Brown, James A.O.C. 2014. 'Azafid Ceuta, Mawlid al-Nabī and the Development of Marīnid Strategies of Legitimation. In The Articulation of Power in Medieval Iberia and the Maghrib, ed. Amira K. Bennison. Oxford: Oxford University Press: 127-51.

Calvo Capilla, Susana. 2012. Madīnat al-Zahrā’ y la observación del tiempo: el renacer de la Antigüedad Clásica en la Córdoba del siglo X. Anales de Historia del Arte 22: 131-60.

- $\quad$ 2014. The Reuse of Classical Antiquity in the Palace of Madinat al-Zahra' and its Role in the Construction of Caliphal Legitimacy. Muqarnas Online 31: 1-33.

Camarero Castellano, Inmaculada. 2015. Sobre el "estado de ŷā'iḥa": Teoría y práctica jurídica de la calamidad rural y urbana en Al-Andalus (ss. VIII-XV). Sevilla: Universidad de Sevilla.

Canto García, Alberto. 1988. El periodo omeya. El Emirato. La aparición de la tipología califal. 'Abd al-Raḥmān III: Sus sucesores. In Actas del I Jarique de Estudios Numismáticos HispanoÁrabes. Saragossa: Institución Fernando el Católico: 29-41.

Carballeira Debasa, Ana María. 2002. Legados píos y fundaciones familiares en al-Andalus (siglos IV/X-VI/XII). Madrid: CSIC.

2003. Pobres y caridad en al-Andalus. In Identidades marginales (Estudios Onomástico-Biográficos de al-Andalus XIII), ed. Cristina de la Puente. Madrid: CSIC: 53-91.

2005. The Role of Endowments in the Framework of Andalusian Society. In Stiftungen in Christentum, Judentum und Islam vor der Moderne, ed. Michael Borgolte. Berlin: Akademie Verlag: 109-21.

2009. Forms and Functions of Charity in al-Andalus. In Charity and Giving in Monotheistic Religions, ed. Yaacov Lev and Miriam Frenkel. Berlin: De Gruyter: 189-202. 
- 2011. Caridad y poder político en época omeya. In Caridad y compasión en biografías islámicas (Estudios Onomástico-Biográficos de al-Andalus XVI), ed. Ana María Carballeira Debasa. Madrid: CSIC: 85-130.

Chalmeta, Pedro. 1988. Le poids des intellectuels hispano-arabes dans l'évolution politique d'al-Andalus. Cahiers de la Méditerranée 37: 107-29.

Chamberlain, Michael. 1994. Knowledge and Social Practice in Medieval Damascus, 11901350. Cambridge: Cambridge University Press.

Clément, François. 1997. Pouvoir et légitimité en Espagne musulmane à l'époque des taifas (Ve-XIe siècles): L'imām fictif. Paris: L'Harmattan.

Crone, Patricia. 2004. Medieval Islamic Political Thought. Edinburgh: Edinburgh University Press.

Dakhlia, Jocelyne. 1996. Du sacré duel au sacré débattu: la légitimité en écho des souverains maghrébins. Al-Qanțara 17: 341-74.

- $\quad$ 1998. Le divan des rois. Le politique et le religieux dans l'Islam. Paris: Editions Aubier.

Echevarría, Ana. 2011. Almanzor: un califa en la sombra. Madrid: Sílex.

Eddé, Anne-Marie. 2011. Saladin, trans. J.M. Todd. Cambridge, MA: Harvard University Press.

El Mansour, Mohamed. 2014. Hospitality, Charity and Political Legitimacy. In The Articulation of Power in Medieval Iberia and the Maghrib, ed. Amira K. Bennison. Oxford: Oxford University Press: 175-91.

Ener, Mine. 2003. The Charity of the Khedive. In Poverty and Charity in Middle Eastern Contexts, ed. Michael Bonner, Mine Ener and Amy Singer. New York: Suny Press: 185-201.

Ephrat, Daphna. 2000. Learned Society in a Period of Transition. New York: State University of New York Press.

Felipe, Helena de. 2014. Berber Leadership and Genealogical Legitimacy: The Almoravid Case. In Genealogy and Knowledge in Muslim Societies: Understanding the Past, ed. Sarah BowenSavant and Helena de Felipe. Edinburgh: Edinburgh University Press: 55-70.

Fierro, Maribel. 1989. Sobre la adopción del título califal por 'Abd al-Raḥmān III al-Nāṣir. Sharq al-Andalus 6: 37-41.

- $\quad$ 1994. La legitimidad del poder en el Islam. Awrāq 15: 155-56.

- 1996. Caliphal Legitimacy and Expiation in al-Andalus. In Islamic Legal Interpretation. Muftis and Their Fatwas, ed. Muhammad K. Masud, Brinkley Messick y David S. Powers. Cambridge: Harvard University Press: 55-63.

2005. 'Abd al-Rahman III. The First Cordoban Caliph, Oxford: Oneworld Publications. 
- 2006. On political legitimacy in al-Andalus: A review article. Der Islam 73: 138-50.

- $\quad$ 2007. The movable minbar in Cordoba: how the Umayyads of al-Andalus claimed the inheritance of the Prophet. Jerusalem Studies of Arabic and Islam 33: 149-68.

2009. Pompa y ceremonia en los califatos del Occidente islámico (s. II/VIII-IX/XV). Cuadernos del Cemyr 17: 125-152.

2010. Apuntes sobre la pobreza y su representación en las sociedades del Occidente islámico medieval (ss. II/VIII-IX/XV). In XXXVI Semana de Estudios Medievales de Estella, 20 a 24 de julio de 2009. Pamplona: Gobierno de Navarra, Institución Príncipe de Viana: 145-174.

2011. Abdarramán III y el califato omeya de Córdoba. San Sebastian: Nerea.

- 2014. Ways of Connecting with the Past: Genealogies in Nasrid Granada. In Genealogy and Knowledge in Muslim Societies: Understanding the Past, ed. Sarah Bowen-Savant and Helena de Felipe. Edinburgh: Edinburgh University Press: 71-88.

García Gómez, Emilio. 1949. La poésie politique sous le califat de Cordoue. Revue des Études Islamiques 1: 5-11.

García Sanjuán, Alejandro. 2002. Hasta que Dios herede la tierra. Los bienes habices en AlAndalus (siglos $X-X V$ ). Huelva: Universidad de Huelva.

2007. Till God Inherits the Earth. Islamic Pious Endowments in al-Andalus (9-15th Centuries). Leiden: Brill.

- 2008. Legalidad islámica y legitimidad política en el Califato de Córdoba: la proclamación de Hišām II. Al-Qanțara 29: 45-77.

Ghrouirgate, Mehdi. 2007. Quelques remarques sur le cérémonial califal almohade. In Le Maghreb, al-Andalus et la Méditerranée occidentale (VIIIe-XIlle siècles), ed. Philippe Sénac. Toulouse: CNRS-Université de Toulouse-Le Mirail: 285-307.

Gómez Rivas, Camilo. 2014. The Ransom Industry and the Expectation of Refuge on the Western Mediterranean Muslim-Christian Frontier, 1085-1350. In The Articulation of Power in Medieval Iberia and the Maghrib, ed. Amira K. Bennison. Oxford: Oxford University Press: 217-32.

Guichard, Pierre. 1990. Quelques réflexions sur le monnayage des premières taifas andalouses (1009/400-1059/451). In Actes del II Jarique de Numismàtica Hispano-Àrab. Lérida: Institut d'Estudis Ilerdencs: 155-161.

- 1995. Al-Manșūr ou al-Manșūr bi-Llāh? Les laqab/s des Amirides d'après la numismatique et les documents officiels. Archéologie islamique 5: 47-53.

- $\quad$ and Bruna Soravia. 2007. Les royaumes des taifas. Apogée culturel et déclin politique des émirats andalous du XIème siècle. Paris: Geuthner.

Halm, Heinz. 1996. The Empire of the Mahdi: the Rise of the Fatimids, trans. M. Bonner. Leiden: Brill. 
Hartung, Jan-Peter. 2011. Enacting the Rule of Islam. On courtly patronage of religious scholars in pre- and early modern times. In Court Cultures in the Muslim World. Seventh to nineteenth centuries, ed. Albrecht Fuess and Jan-Peter Hartung. London: Routledge: 296-325.

Hees, Syrinx von. 2011. The Guidance for Kingdoms: Function of a "mirror for princes" at court and its representation of a court. In Court Cultures in the Muslim World. Seventh to Nineteenth Centuries, ed. Albrecht Fuess and Jan-Peter Hartung. London: Routledge: 370-82.

Heidemann, Stephan. 2009. Frömmigkeit und Wohltätigkeit für die städtische Erneuerung. Abgaben- und Stiftungspolitik in der Mitte des 12. Jahrhunderts. In Islamische Stiftungen zwischen juristischer Norm und sozialer Praxis, ed. Astrid Meier, Johannes Pahlitzsch and Lucian Reinfandt. Berlin: Oldenbourg Akademie Verlag: 61-78.

Hoexter, Miriam. 2003. Charity, the Poor, and Distribution of Alms in Ottoman Algiers. In Poverty and Charity in Middle Eastern Contexts, ed. Michael Bonner, Mine Ener and Amy Singer. New York: Suny Press: 145-63.

Imber, Colin. 1997. Ebu's-Su'ud: The Islamic Legal Tradition. Edinburgh: Edinburgh University Press.

Krasner Balbale, Abigale. 2014. Jihād as a Means of Political Legitimization in ThirteenthCentury Sharq al-Andalus. In The Articulation of Power in Medieval Iberia and the Maghrib, ed. Amira K. Bennison. Oxford: Oxford University Press: 87-105.

Lev, Yaacov. 2000. Charity and Social Practice: Egypt and Syria in the Ninth-Twelfth Centuries. Jerusalem Studies in Arabic and Islam 24: 475-81.

2005. Charity, Endowments, and Charitable Institutions. Gainesville: University Press of Florida.

2009. Charity and Gift Giving in Medieval Islam. In Charity and Giving in Monotheistic Religions, ed. Yaacov Lev and Miriam Frenkel. Berlin: De Gruyter: 249-58.

Lewis, Bernard. 1988. The Political Language of Islam. Chicago: The University of Chicago Press.

Makdisi, George. 1990. History and Politics in Eleventh-Century Baghdad. Aldershot: Variorum.

Martínez, Virgilio and Antonio Torremocha. 2001. Almanzor y su época. Malaga: Sarriá.

Martínez-Gros, Gabriel. 1992. L'idéologie omeyyade: la construction de la légitimité du califat de Cordoue (X-XI siècles). Madrid: Casa de Velázquez.

Mauss, Marcel. 1990. The Gift: The Form and Reason for Exchange in Archaic Societies. London: Routledge.

Meouak, Mohamed. 1995. Représentations, emblèmes et signes de la souveraineté politique des Umayyades d'al-Andalus d'après les textes arabes. Acta Orientalia 56: 78-105. 
- $\quad$ 1999. Pouvoir souverain, administration centrale et élites politiques dans l'Espagne umayyade (IIe-IVe/VIIIe-Xe siècles). Helsinki: Academia Scientiarum Fennica.

Monés, Hussain. 1964. Le rôle des hommes de religion dans l'Histoire de l'Espagne musulmane jusqu'à la fin du califat. Studia Islamica 20: 47-88.

Mottahedeh, Roy P. 1980. Loyalty and Leadership in an Early Islamic Society. Princeton: Princeton University Press.

Müller, Christian. Redressing injustice: Maz̄allim jurisdictions at the Umayyad court of Córdoba (eighth-eleventh centuries CE). In Court Cultures in the Muslim World. Seventh to Nineteenth Centuries, ed. Albrecht Fuess and Jan-Peter Hartung. London: Routledge: 93-104.

Nef, Annliese. 2011. Instruments de la légitimation politique et légitimité religieuse dans l'Ifrīqiya de la fin du IX'e siècle: l'exemple d'Ibrāhīm II (875-902). In La légitimation du pouvoir au Maghreb médiéval. De l'orientalisation à l'émancipation politique, ed. Annliese Nef and Élise Voguet. Madrid: Casa de Velázquez: 75-91.

Özbek, Nadir. 2003. Imperial Gifts and Sultanic Legitimation during the Late Ottoman Empire, 1876-1909. In Poverty and Charity in Middle Eastern Contexts, ed. Michael Bonner, Mine Ener and Amy Singer. New York: Suny Press: 203-20.

Peláez Rovira, Antonio. 2011. El Maristán de Granada al servicio del poder nazarí: el uso político de la caridad. In Caridad y compasión en biografías islámicas (Estudios OnomásticoBiográficos de al-Andalus XVI), ed. Ana María Carballeira Debasa. Madrid: CSIC: 131-70.

Peri, Oded. 1983. The Waqf as an Instrument to Increase and Consolidate Political Power: The Case of the Khassekī Sultān Waqf in Late 18th Century Jerusalem. Asian and African Studies, 17: 47-62.

Pinckney, Suzanne. 1997. The Qașīdah and the Poetics of Ceremony: Three 'Īd Panegyrics to the Cordoban Caliphate. In Languages of Power in Islamic Spain, ed. Ross Brann. Ithaca: CDL Press: 1-48.

Puente, Cristina de la. 1997. La caracterización de Almanzor: entre la epopeya y la historia. In Estudios Onomástico-Biográficos de al-Andalus VIII, ed. María Luisa Ávila and Manuela Marín. Madrid: CSIC: $367-402$.

Reid, Megan H. 2013. Law and Piety in Medieval Islam. Cambridge: Cambridge University Press: 97-143.

Robinson, Cynthia and Amalia Zomeño. 2014. On Muhammad V, Ibn al-Khațīb and Sufism. In The Articulation of Power in Medieval Iberia and the Maghrib, ed. Amira K. Bennison. Oxford: Oxford University Press: 153-74.

Rodríguez Mañas, Francisco. 2000. Charity and Deceit: The Practice of the It'ām al-ta'ām in Moroccan Sufism. Studia Islamica 91: 59-90. 
Sabra, Adam. 2000. Poverty and Charity in Medieval Islam: Mamluk Egypt, 1250-1517. Cambridge: Cambridge University Press.

Safran, Janina. 1998. The Command of the Faithful in al-Andalus: A Study in the Articulation of Caliphal Legitimacy. International Journal of Middle Eastern Studies 30: 183-98. 1999. Ceremony and Submission: The Symbolic Representation and Recognition of Legitimacy in Tenth-Century al-Andalus. Journal of Near Eastern Studies 58: 191-201.

2000. The Second Umayyad Caliphate: The Articulation of Caliphal Legitimacy in alAndalus. Cambridge, MA: Harvard University Press.

Scales, Peter C. 1994. The Fall of the Caliphate of Córdoba: Berbers and Andalusis in Conflict. Leiden: Brill.

Sénac, Philippe. 2006. Al-Mansur: le fléau de l'an mil. Paris: Perrin.

Shatzmiller, Maya. 1991. Royal Waqf in 14th-century Fez. Anaquel de Estudios Árabes 2: 193-217.

Singer, Amy. 2008. Charity in Islamic Societies. Cambridge: Cambridge University Press.

Vidal Castro, Francisco. 2008. Los cautivos en al-Andalus durante el Califato Omeya de Córdoba: aspectos jurídicos, sociales y económicos. Miscelánea de Estudios Árabes y Hebraicos. Sección Árabe-Islam 57: 359-398.

Viguera Molins, María Jesús. 1994. El poder político: ejercicio de la soberanía. In Historia de España de Ramón Menéndez Pidal, VIII-1. Los Reinos de Taifas, coord. María Jesús Viguera Molins. Madrid: Espasa-Calpe: 133-50.

1995. Ceremonias y símbolos soberanos en al-Andalus: notas sobre la época almohade. In Casas y Palacios de al-Andalus: siglos XII y XIII, ed. Julio Navarro Palazón and Pedro Jiménez Castillo. Granada: Legado Andalusí-Lunwerg Editores: 105-15.

2011. La compasión, virtud del sultán, en el Musnad de Ibn Marzūq. In Caridad y compasión en biografías islámicas (Estudios Onomástico-Biográficos de al-Andalus XVI), ed. Ana María Carballeira Debasa. Madrid: CSIC: 173-206.

Wasserstein, David J. 1993. Caliphate in the West: an Islamic Political Institution in the Iberian Peninsula. New York: Clarendon Press.

Zomeño, Amalia. 2004. En los límites de la juventud: niñez, pubertad y madurez en el derecho islámico medieval. Mélanges de la Casa de Velázquez 31: 85-98.

\section{ABBREVIATIONS}

Coord. $=$ coordinator 
Ed. = editor/edition

Trans. $=$ translation

Vol. = volume 